\title{
Kontroversi Sanksi Denda Pada Vaksinasi Covid-19 Dalam Perspektif Undang-Undang No. 36 Tahun 2009 Tentang Kesehatan
}

\author{
Otih Handayani \\ Fakultas Hukum, Universitas Bhayangkara Jakarta Raya \\ Email: otih.handayani@gmail.com
}

Article info

Received: Apr 2, $2021 \quad$ Revised: May 14, $2021 \quad$ Accepted: May 22, $2021 \quad$ Published: Jun 10, 2021

DOI: https://doi.org/10.31599/krtha.v15i1.557

Keywords : vaccines, sanctions, justice

Abstract : Health is a human right and the State is responsible for the provision of health service facilities for every Indonesian citizen as mandated by Article $28 \mathrm{H}$ number (1) and Article 34 number (3) of the 1945 Constitution. covid-19. This researcher aims to examine the application of the rules or norms in positive law which are then linked to the discussion that becomes the subject of discussion. normative juridical legal research is carried out by examining formal legal rules such as laws, regulations and literature containing theoretical concepts. The results of the study describe that in Presidential Decree no. 14 of 2021 states that every person who has been designated as a target recipient of the Covid-19 vaccine and does not participate in the Covid-19 vaccination can be subject to a fine. Another thing is that vaccine recipients are healthy people who have actually not committed health violations so that this regulation does not reflect the principle of justice as stated in article 2 of Law No. 36 of 2009 concerning Health.

Kata kunci : vaksin, sanksi, keadilan

Abstrak : Kesehatan merupakan Hak Asasi Manusia dan Negara bertanggung jawab atas penyediaan fasilitas pelayanan kesehatan setiap warga negara Indonesia sebagaimana amanah Pasal 28H angka (1) dan Pasal 34 angka (3) UUD 1945. Pada Pandemic Covid-19, Pemerintah memimplementasikan dengan pengadaan vaksin dan pelaksanaan vaksinasi Covid-19. Penelitian ini bertujuan untuk mengkaji penerapan kaidah-kaidah atau norma-norma dalam hukum yang positif yang kemudian dihubungkan dengan pembahasan yang menjadi pokok pembahasan. Penelitian hukum yuridis normatif dilakukan dengan cara mengkaji aturan hukum bersifat formil seperti undang-undang, peraturan serta literatur yang berisi konsepkonsep teoritis. Hasil penelitian mendiskripsikan bahwa Dalam Perpres No. 14 tahun 2021 menyatakan bahwa Setiap orang yang telah ditetapkan sebagai sasaran penerima vaksin Covid- 19 dan tidak mengikuti vaksinasi Covid-19 dapat dikenai sanksi denda. Hal lain adalah penerima vaksin adalah orang sehat yang sesungguhnya tidak melakukan pelanggaran kesehatan sehingga peraturan ini tidak mencerminkan Asas keadilan sebagaimana tertera dalam pasal 2 Undang-Undang No. 36 tahun 2009 tentang Kesehatan. 


\section{PENDAHULUAN}

Coronavirus Disease 2019 (COVID-19) telah dinyatakan oleh World Health Organization sebagai global pandemic dan di Indonesia dinyatakan sebagai jenis penyakit yang menimbulkan kedaruratan kesehatan masyarakat serta bencana non alam, yang tidak hanya menyebabkan kematian tapi juga menimbulkan kerugian ekonomi yang cukup besar. Pandemic Covid-19 memaksa berubah secara dratis dan sangat cepat di hampir seluruh sendi kehidupan baik ekonomi, politik, sosial budaya, pertahanan dan keamanan. Diperlukan berbagai langkah strategis di sisi Pemerintah dan partisipasi aktif dari masyarakat dalam menangani kondisi ini.

Data kasus Covid-19 per 1 April 2021 di seluruh dunia mencapai 129 juta kasus, pasien sembuh 73,2 juta dan meninggal 2,8 juta sedangkan di Indonesia telah mencapai 1.5 juta kasus, pasien sembuh 1,3 juta dan meninggal 41 ribu jiwa. ${ }^{1}$ Pelayanan kesehatan preventif sebagai suatu kegiatan pencegahan terhadap suatu masalahkesehatan/penyakit ${ }^{2}$ sangat dibutuhkan dalam upaya untuk memelihara dan meningkatkan derajat kesehatan masyarakat yang setinggi-tingginya dalam rangka pembentukan sumber daya manusia Indonesia, serta peningkatan ketahanan dan daya saing bangsa bagi pembangunan nasional. Pandemic Covid-19 menyebabkan terjadinya gangguan kesehatan pada masyarakat Indonesia akan menimbulkan kerugian ekonomi yang besar bagi negara, dan setiap upaya peningkatan derajat kesehatan masyarakat juga berarti investasi bagi pembangunan negara.

Tanggung jawab negara sebagaimana termaktub dalam tujuan Negara yang terdapat dalam alinea keempat Pembukaan Undang-Undang Dasar Negara Republik Indonesia Tahun 1945 yaitu melindungi segenap bangsa Indonesia dan seluruh tumpah darah Indonesia, memajukan kesejahteraan umum, mencerdaskan kehidupan bangsa, dan ikut melaksanakan ketertiban dunia yang berdasarkan kemerdekaan, perdamaian abadi dan keadilan sosial, dalam upaya menanggulangi Pandemic Covid-19 pemenuhan vaksin Covid-19 merupakan pelaksanaan amanah dari tujuan negara. ${ }^{3}$ Pengadaan vaksin dan pelaksanaan vaksinasi covid-19 ini guna percepatan dan penanggulangan pandemic Covid-19.

${ }^{1}$ https://www.bing.com/search?qjumlah penderita covid-19

${ }^{2}$ Undang-Undang Republik IndonesiaNomor 36 Tahun 2009 Tentang Kesehatan pasal 1 angka (13).

${ }^{3}$ Muh. Ali Masnun, Eny Sulistyowati, Irfa Ronaboyd, Pelindungan Hukum Atas V aksin Covid-19 Dan Tanggung Jawab Negara Pemenuban Vaksin Dalam Mewnjudkan Negara Kesejabteraan, Jurnal Ilmu Hukum Volume 17 No. 1 tahun 2021 
Sesungguhnya uji coba terburu-buru dapat menghasilkan Vaksin Covid-19 kurang berkualitas, umumnya, pengembangan vaksin bisa berlangsung antara 6-15 tahun, dikarenakan harus melewati berbagai tahap penelitian, uji praklinis, uji klinis tahap 1, 2, dan 3, sampai bisa didistribusikan dan dipasarkan kepada masyarakat. Namun, dalam kondisi pandemi seperti sekarang ini, diperlukan kecepatan agar bisa menyelamatkan umat sehinga perlu mempersingkat waktu. ${ }^{4}$ Badan Pengawas Obat dan Makanan (BPOM) RI akhirnya memberi izin penggunaan darurat atau Emergency Use Authorization (EUA) untuk vaksin Corona Sinovac yaitu CoronaVac. Kepala BPOM Penny K Lukito menjelaskan beberapa efek samping ringan hingga sedang vaksin Sinovac yang ditemukan selama uji klinis berupa nyeri, iritasi, pembengkakan, serta efek samping sistemik berupa nyeri otot, fatigue, dan demam. Adapun efek samping berat berupa sakit kepala, gangguan di kulit, serta diare dalam jumlah yang tidak banyak dan menurutnya tidak berbahaya. ${ }^{5}$

Project Senior Integration Manager Research and Development PT Bio Farma Neni Nuraini menyebutkan bahwa Kemenkes, WHO dan Unicef, telah melaksanakan survei tentang persepsi masyarakat tentang vaksin Covid-19 dan bahwa 64,8 persen keluarga akan ikut vaksinasi, 27,6 persen yang mengatakan belum tahu, sedangkan 7,6 persen tidak mau divaksin dengan alasan tidak yakin dengan keamanan vaksin, tidak yakin dengan efektivitasnya, takut terhadap efek samping, sampai alasan kepercayaan agama dan alasan lainnya. ${ }^{6}$

Adanya penolakan sejumlah warga untuk melakukan vaksinasi yang disebabkan takut efek samping setelah divaksin. ${ }^{7}$ Anggota Komisi IX DPR RI Fraksi PDI Perjuangan (PDIP) Ribka Tjiptaning tegas menolak divaksinasi Covid-19 dalam rapat kerja Komisi IX DPR dengan Menteri Kesehatan Budi Gunadi Sadikin, Selasa 12 Januari 2021 dengan alasan belum ada satupun pihak yang dapat memastikan keamanan vaksin Covid -19 asal perusahaan China, Sinovac. Ia bahkan rela membayar jika ada sanksi bagi para pihak yang menolak untuk divaksin. ${ }^{8}$

4 ibid

${ }^{5}$ https://health.detik.com/berita-detikhealth/d-5329447/BPOM Jelaskan Efek Samping Vaksin Sinovac yang Sudah Kantongi Izin EUA

6 https://kabar24.bisnis.com/read/20201026/15/1309845 Bio Farma: 7,6 Persen Orang Menolak Divaksin. Apa Alasannya?

${ }^{7}$ https://mediaindonesia.com/nusantara/386919/Masih Ada Warga Menolak Vaksinasi Covid19 di Temanggung

${ }^{8}$ https://www.tribunnews.com/nasional/2021/01/13/Politisi PDIP Ribka Tjiptaning Menolak Divaksinasi, "Mending Saya Bayar Rp 5 Juta" 
Penolakan juga terjadi terhadap vaksin AstraZeneca di Ponpes Amanatul

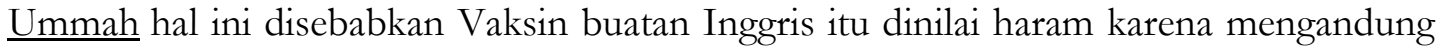
tripsin pankreas babi. Penolakannya tersebut salah satunya berpedoman pada Fatwa MUI pusat yang menyatakan vaksin AstraZeneca haram, tapi boleh digunakan dalam kondisi darurat. Kiai Asep melarang keras vaksin AstraZeneca disuntikkan ke 12.000 santri dan mahasiswa, serta 1.000 lebih tenaga pendidik Amanatul Ummah, hal ini terkait dengan tidak dalam kondisi darurat dikarena belum ada seorang pun di lingkungan pesantren yang terinfeksi Covid-19 selama setahun lebih pandemi. ${ }^{9}$

Indonesia sebagai negara hukum, oleh karenanya pencegahan terhadap jenis penyakit menular dalam hal ini Covid-19 wajib dibentuk dalam sebuah aturan atau regulasi. ${ }^{10}$ Untuk menjamin berjalannya vaksinasi sebagai upaya penanggulan pandemic Covid-19 pemerintah mengeluarkan peraturan diantaranya Peraturan Presiden No. 99 Tahun 2020 tentang Pengadaan Vaksin dan Pelaksanaan Vaksinasi Dalam Rangka Penanggulangan Pendemic Corona Virus Disease 2019 (Covid-19), Peraturan Presiden No. 14 tahun 2021 dan beberapa Peraturan Daerah diantaranya Perda Provinsi DKI No. 2 tahun 2020 tentang Penanggulangan Corona Virus Disease 2019.

Kontroversi muncul terkait adanya sanksi administratif maupun pidana bagi setiap orang yang menolak melaksanakan vaksinasi Covid-19 baik yang termaktub dalam Peraturan Presiden dan juga Peraturan Daerah diantaranya Peraturan Daerah Provinsi Daerah Khusus Ibukota Jakarta Nomor 2 Tahun 2020 yaitu ancaman pidana denda paling banyak sebesar Rp 5.000.000,00 (lima juta rupiah) bagi setiap orang yang dengan sengaja menolak untuk dilakukan vaksinasi Covid-19. ${ }^{11}$

State of the art penelitian ini diambil dari penelitian terdahulu dalam bentuk jurnal di antaranya penelitian oleh Muh. Ali Masnun, Eny Sulistyowati, Irfa Ronaboyd Fakultas Hukum Universitas Negeri Surabaya pada Jurnal Ilmu Hukum Volume 17 No. 1 tahun 2021 berjudul Pelindungan Hukum Atas Vaksin Covid-19 Dan Tanggung Jawab Negara Pemenuban Vaksin Dalam Mewrijudkan Negara Kesejabteraan, dengan kesimpulan bahwa Eksklusivitas vaksin Covid-19 dalam HKI bukanlah sebuah hal yang dapat dieksploitasi tanpa batas, melainkan Negara dapat hadir sebagai bentuk tanggung jawabnya melalui

\footnotetext{
${ }^{9}$ https://news.detik.com/berita-jawa-timur/d-5510181/ Alasan Pengasuh Ponpes di Mojokerto Tolak Vaksin AstraZeneca.

${ }^{10}$ Dalinama Telaumbanua, Urgensi Pembentukan Aturan Terkait Pencegahan Covid-19 di Indonesia, Jurnal Qalamuna, Vol 12 No 1 (2020)

${ }^{11}$ Peraturan Daerah Provinsi Daerah Khusus Ibukota Jakarta Nomor 2 Tahun 2020 pasal 30
} 
penerapan lisensi wajib atau pengungkapan informasi yang bersifat rahasia ${ }^{12}$ dan Dalinama Telaumbanua, Sekolah Tinggi Ilmu Hukum Nias Selatan, Pada Jurnal Qalamuna Vol 12 No. 1, 2020 berjudul Urgensi Pembentukan Aturan Terkait Pencegahan Covid19 Di Indonesia, dengan kesimpulan bahwa pembentukan aturan terkait dengan pencegahan covid-19 ini wajib dibentuk guna memberi kepastian hukum dalam mencegah menularnya Covid-19 secara meluas. ${ }^{13}$ Kebaruan dari penelitian ini terletak pada analisis sanksi denda pada vaksinasi Covid-19 yang tercantum baik dalam Peraturan Presiden maupun Peraturan Daerah.

Penelitian ini mengunakan Stufenbau Theory-Stufenbau des Recht dari Hans Kelsen dan Hans Nawiasky tentang hierarki perundang-undangan serta teori keadilan Amartya Sen, dimana ide keadilan sebagai upaya untuk mengurangi ketidakadilan. Hal yang paling mendasar bagi hidup manusia sejatinya adalah adanya kemampuan (ability), jika ia memiliki kemampuan itu, maka ia memiliki kapabilitas, namun jika ia tidak memilikinya, makaia kehilangan kapabilitas (deprivasi kapabilitas) diantaranya orang atau masyarakat yang tidak bisa makan, tidak bisa mengakses kesehatan dan juga orang yang tidak bisa berpendapat secara bebas di muka umum.

Artikel ini bertujuan untuk menganalisis tentang sanksi pidana denda dalam Peraturan Presiden dan Peraturan Daerah serta bagaimana keadilan bagi masyarakat yang tidak memiliki kemampuan sebagai bagian dari masyarakat yang terpapar pandemic Covid-19 dalam perspektif Undang-Undang No. 36 Tahun 2009 tentang Kesehatan.

\section{METODE PENELITIAN}

Metode yang digunakan dalam penelitian ini adalah penelitian yuridis normatif. Penelitian yang fokus untuk mengkaji penerapan kaidah-kaidah atau norma-norma dalam hukum positif yang kemudian di hubungkan dengan pembahasan yang menjadi pokok penelitian. Dalam penelitian ini menggunakan sumber hukum primer seperti Undang-UUD NRI 1945, UU No. 36 Tahun 2009 tentang Kesehatan, UU No. 11 Tahun 2012 tentang Pembentukan Peraturan Perundang-undangan, PerPres No. 99 Tahun 2020 tentang Pengadaan Vaksin dan Pelaksanaan Vaksinasi Dalam Rangka Penanggulangan Pendemic Corona Virus Disease 2019 (Covid-19), PerPres No. 14 tahun 2021 Tentang Perubahan

12 Muh. Ali Masnun, Eny Sulistyowati Irfa Ronaboyd, Pelindungan Hukum Atas Vaksin Covid-19 Dan Tanggung Jawab Negara Pemenuban Vakesin Dalam Mewnjudkan Negara Kesejabteraan, Jurnal Ilmu Hukum Volume 17 No. 1 tahun 2021.

${ }^{13}$ Dalinama Telaumbanua, Urgensi Pembentukan Aturan Terkait Pencegahan Covid-19 di Indonesia, Jurnal Qalamuna, Vol 12 No 1 (2020) 
Peraturan Presiden No. 99 Tahun 2020 serta Perda DKI Jakarta No. 2 Tahun 2020 tentang Penanggulangan Corona Virus Disease-2019. Sumber hukum sekunder berasal dari hasil penelitian, karya ilmiah termasuk diantaranya berbagai jurnal, sedangkan sumber hukum tersier berasal berasal dari kamus bahasa hukum, ensiklopedi, majalah, media massa dan internet.

\section{PEMBAHASAN}

\section{A. Urgensi Vaksinasi}

Covid-19 telah menjadi masalah global, hingga saat ini pandemi virus Corona belum juga berakhir. Diperlukan langkah-langkah yang tepat dan cepat guna menekan kasus yang terus bertambah. Melihat data saat ini maka percepatan penanggulang pandemic ini menjadi wajib salah satunya adalah upaya pencegahan melalui vaksinasi, sebab: ${ }^{14}$

1. Vaksin diperuntukkan untuk melindungi tubuh dari serangan penyakit tertentu sehingga membantu mencegah penyebaran penyakit. Vaksin yang dimasukkan ke dalam tubuh umumnya mengandung virus atau bakteri yang telah dilemahkan, serta protein mirip bakteri yang diperoleh dari pengembangan di laboratorium.

2. Pemberian vaksin merupakan salah satu investasi kesehatan yang paling murah karena dapat mencegah, mengurangi angka kesakitan, kecacatan, dan kematian akibat suatu penyakit.

Vaksinasi membuat sistem kekebalan tubuh seseorang mampu mengenali dan dengan cepat melawan bakteri atau virus penyebab infeksi. Tujuan yang ingin dicapai dengan pemberian vaksin COVID-19 adalah menurunnya angka kesakitan dan angka kematian akibat virus ini. vaksinasi Covid-19 mendorong terbentuknya herd immunity atau kekebalan kelompok. Hal ini penting karena ada sebagian orang yang tidak bisa divaksin karena alasan tertentu, dengan mendapatkan vaksinasi tidak hanya melindungi diri sendiri, tapi juga orang-orang di sekitar yang belum memiliki kekebalan terhadap virus Corona.

${ }^{14}$ https://www.alodokter.com/Manfaat Vaksin Penting untuk Mencegah Penularan Penyakit 


\section{B. Peraturan Yang Terbit Terkait Vaksinasi Covid-19}

Pemerintah menargetkan vaksinasi Covid-19 terhadap 181,5 juta penduduk Indonesia untuk menciptakan kekebalan komunal. ${ }^{15}$ untuk mengawal target tersebut berikut adalah beberapa peraturan yang terkait dengan pelaksanaan vaksinasi Covid-19 :

1. Peraturan Presiden No. 14 tahun 2021 tentang Perubahan atas Perpres No. 99 Tahun 2020 tentang Pengadaan Vaksin dan Pelaksanaan Vaksinasi dalam Rangka Penanggulangan Pandemi Covid-19.

a. Pasal 13A angka (1) Kementerian Kesehatan melakukan pendataan dan menetapkan sasaran penerima vaksin Covid-19; angka (2) Setiap orang yang telah ditetapkan sebagai sasaran penerima vaksin Covid-19 berdasarkan pendataan sebagaimana dimaksud pada Ayat (1) wajib mengikuti vaksinasi Covid- 1 9; angka (3) Dikecualikan dari kewajiban sebagaimana dimaksud pada Ayat (2) bagi sasaran penerima vaksin Covid-19 yang tidak memenuhi kriteria penerima vaksin Covid-19 sesuai dengan indikasi vaksin Covid-19 yang tersedia; angka (4) Setiap orang yang telah ditetapkan sebagai sasaran penerima baksin Covid- 19 yang tidak mengikuti vaksinasi Covid-19 sebagaimana dimaksud pada Ayat (2) dapat dikenai sanksi administratif berupa:a). penundaan atau penghentian pemberian jaminan sosial atau bantuan sosial; b) penundaan atau penghentian layanan administrasi pemerintahan; dan/atau c) denda; angka (5) Pengenaan sanksi administratif sebagaimana dimaksud pada Ayat (4) dilakukan oleh kementerian, lembaga, pemerintah daerah, atau badan sesuai dengan kewenangannya.

b. Pasal 13B : Setiap orang yang telah ditetapkan sebagai sasaran penerima vaksin Covid- 19, yang tidak mengikuti vaksinasi Covid-19 sebagaimana dimaksud dalam Pasal 13A Ayat (2) dan menyebabkan terhalangnya pelaksanaan penanggulangan penyebaran Covid-19, selain dikenai sanksi sebagaimana dimaksud dalam Pasal 13A ayat a dapat dikenai sanksi sesuai dengan ketentuan Undang-Undang tentang Wabah Penyakit Menular.

c. Pada Pasal 15A ayat (1) Dalam rangka pemantauan kejadian ikutan pasca Vaksinasi Covid-19 dilakukan pencatatan dan pelaporan serta investigasi;

15 https://www.liputan6.com/news/read/4482967/Melihat Lagi Perpres Sanksi bagi Warga yang Menolak Vaksinasi 
Ayat (2) pencatatan dan pelaporan serta investigasi sebagaimana ayat (1) dilakukan oleh Fasilitas Pelayanan Kesehatan atau Dinas Kesehatan sesuai dengan ketentuan peraturan perundang-undangan ; Ayat (3) Berdasarkan hasil pencatatan dan pelaporan serta investigasi, dijelaskan pada ayat (2), dilakukan kajian etiologi lapangan oleh Komite Daerah Pengkajian dan Penanggulangan Kejadian Ikutan Pasca Imunisasi dan kajian kausalitas oleh Komite Nasional Pengkajian dan Penanggulangan Kejadian Ikutan Pasca Imunisasi; Ayat (4) Terhadap kasus kejadian ikutan pasca Vaksinasi Covid-19 sebagaimana dimaksud pada ayat (1) dilakukan pengobatan dan perawatan sesuai dengan indikasi medis dan protokol pengobatan, maka biaya pengobatan dan perawatan dilaksanakan dengan ketentuan: a) untuk peserta Program Jaminan Kesehatan Nasional yang aktif, ditanggung melalui mekanisme Jaminan Kesehatan Nasional, dan b) untuk peserta Program Jaminan Kesehatan Nasional yang nonaktif dan selain peserta Program Jaminan Kesehatan Nasional didanai melalui mekanisme pendanaan lain yang bersumber dari anggaran pendapatan dan belanja negara yang dilaksanakan sesuai dengan ketentuan peraturan perundang-undangan di bidang keuangan negara.

d. Pasal 15B ayat (1)Dalam hal terdapat kasus kejadian ikutan pasca vaksinasi yang dipengaruhi oleh produk Vaksin Covid-19 berdasarkan hasil kajian kausalitas sebagaimana dimaksud dalam pasal 15A ayat (3) dan kasus tersebut menimbulkan kecacatan atau meninggal, diberikan kompensasi oleh Pemerintah; Ayat (2) Kompensasi sebagaimana dimaksud pada ayat (1) berupa santunan cacat atau santunan kematian ; Ayat (3) Ketentuan lebih lanjut mengenai kriteria, bentuk, dan nilai besaran untuk kompensasi tersebut ditetapkan oleh Menkes setelah mendapat persetujuan dari Menteri Keuangan. ${ }^{16}$

2. Undang-undang UU No 4 Tahun 1984 tentang Wabah Penyakit Menular

a. Pasal 14 angka (1) Barang siapa dengan sengaja menghalangi pelaksanaan penanggulangan wabah sebagaimana diatur dalam UU ini diancam dengan pidana penjara selama-lamanya 1 tahun dan/atau denda setinggi-tingginya

16 https://www.menpan.go.id/site/berita-terkini/dari-istana/Inilah Perpres 14/2021 tentang Pengadaan Vaksin dan Pelaksanaan Vaksinasi COVID-19 (menpan.go.id) 
Rp1.000.000,-; angka (2) (2) Barang siapa karena kealpaannya mengakibatkan terhalangnya pelaksanaan penanggulangan wabah sebagaimana diatur dalam UU ini diancam dengan pidana kurungan selama-lamanya 6 bulan dan/atau denda setinggi-tingginya Rp 500.000,-.

b. Pasal 15 angka (1) Barang siapa dengan sengaja mengelola secara tidak benar bahan-bahan sebagaimana diatur dalam UU ini sehingga dapat menimbulkan wabah diancam dengan pidana penjara selama-lamanya 10 tahun dan/atau denda setinggi-tingginya Rp100 juta; angka (2) Barang siapa karena kealpaannya mengelola secara tidak benar bahan-bahan sebagaimana diatur dalam UU ini sehingga dapat menimbulkan wabah, diancam dengan pidana kurungan selama-lamanya 1 tahun dan/atau denda setinggi-tingginya Rp 10 juta; angka (3) Apabila tindak pidana sebagaimana dimaksud dalam Ayat (1) dilakukan oleh suatu badan hukum diancam dengan pidana tambahan berupa pencabutan izin usaha.

3. Peraturan Daerah Provinsi Daerah Khusus Ibukota Jakarta Nomor 2 Tahun 2020 Pasal 30 : Setiap orang yang dengan sengaja menolak untuk dilakukan pengobatan dan/atau vaksinasi Covid-19, dipidana dengan pidana denda paling banyak sebesar Rp 5.000.000,00 (lima juta rupiah). ${ }^{17}$

\section{Kesehatan Warga Negara}

Definisi kesehatan menurut Undang-undang Nomor 36 Tahun 2009 Tentang Kesehatan adalah keadaaan sejahtera dari fisik, mental dan sosial yang memungkinkan setiap orang hidup produktif secara sosial dan ekonomi. Sedangkan menurut WHO :

"Kesehatan adalah suatu keadaan sejabtera fisik, mental dan sosial yang lengkap dan bukan hanya bebas dari penyakit atau kecacatan. Dari dua defenisi di atas dapat diambil kesimpulan babwa untuk dikatakan sehat, seseorang harusberada pada suatu kondisi fisik, mental dan sosial yang bebas dari gangguan, seperti penyakit atau perasaan tertekan yang memungkinkan seseorang tersebut untuk bidup produktif dan mengendalikan stres yang terjadi sebari-hari serta berbubungan sosial secara nyaman dan berkualitas".

Adapun yang dimaksud dengan Hukum Kesehatan adalah :

"Semua ketentuan bukum yang berbubungan langsung dengan pemelibaraan/pelayanan kesehatan dan penerapannya. Hal inimenyangkut hak dan kewajiban baik dari perorangan dansegenap lapisan masyarakat sebagai penerima pelayanan kesehatan maupun dari pibak penyelenggara pelayanankesehatan dalam segala aspeknya, organisasi, sarana, pedoman standar

${ }^{17}$ Peraturan Daerah Provinsi Daerah Khusus Ibukota Jakarta Nomor 2 Tahun 2020 pasal 30 
pelayanan medik, ilmu pengetabuan kesehatan dan bukum serta sumber-sumber bukum lainnya". ${ }^{18}$

Kesehatan merupakan hak asasi manusia dan salah satu unsur kesejahteraan yang sangat penting bagi kemajuan suatu negara oleh karenanya harus diwujudkan sesuai dengan cita-cita bangsa Indonesia sebagaimana dimaksud dalam Pancasila dan UndangUndang Dasar Negara Republik Indonesia Tahun 1945 ; Pasal 28H angka (1) Setiap orang berhak hidup sejahtera lahir dan batin, bertempat tinggal, dan mendapatkan lingkungan hidup yang baik dan sehat serta berhak memperoleh pelayanan kesehatan; Pasal 34 angka (3) UUD 1945 Negara bertanggung jawab atas fasilitas pelayanan kesehatan dan fasilitas pelayanan umum yang layak.

Dalam Hukum Kesehatan terdapat 5 (lima) fungsi yang mendasar (Jayasuriya), yang terdiri dari $:^{19}$

1. Pemberian hak,

2. Penyediaan perlindungan,

3. Peningkatan kesehatan,

4. Pembiayaan kesehatan,

5. Penilaian terhadap kuantitas dan kualitas dalam pemeliharaan kesehatan

Asas Hukum Kesehatan bertumpu pada: hak atas pemeliharaan kesehatan sebagai hak dasar social (the right to health care) yang ditopang oleh 2 (dua) hak dasar individual yang terdiri dari: ${ }^{20}$

1. hak atas informasi (the right to information) dan

2. hak untuk menentukan nasib sendiri (the right of self determination) (hermien hadiati)

\section{Pidana Denda Dalam Peraturan Presiden Dan Peraturan Daerah}

Menurut teori Hierarki Norma Hukum (Stufenbau Theory-Stufenbau des Recht) dari Hans Kelsen, norma-norma hukum itu berjenjang-jenjang dan berlapis-lapis dalam suatu hierarki (tata susunan), dalam arti, suatu norma yang lebih rendah berlaku, bersumber dan berdasar pada norma yang lebih tinggi, norma yang lebih tinggi berlaku, bersumber dan berdasar pada norma yang lebih tinggi lagi, demikian seterusnya sampai pada suatu norma yang tidak dapat ditelusuri lebih lanjut dan bersifat hipotetis dan fiktif

18 Amri Amir, Bunga Rampai Hukum Kesehatan, Widya Medika, Jakarta, 1997, hlm.10

${ }^{19}$ Erfen G.Suwangto, Pengantar Hukum Kesehatan, Departemen Bioetika dan Hukum Kesehatan Fakultas Kedokteran Unika Atma Jaya Jakarta, 2016, hlm. 60

${ }^{20}$ Ibid, hlm 61 
yaitu Norma Dasar (Grundnorm). ${ }^{21}$ Hans Nawiasky, menyempurnakan Stufenbau Theory tersebut bahwa selain norma itu berlapis-lapis dan berjenjang-jenjang, norma hukum dari suatu negara itu juga berkelompok-kelompok, dan pengelompokkan norma hukum dalam suatu negara tersusun dalam Tata Susunan Norma Hukum Negara (die Stufenordnung der Rechtsnormen) dalam empat tingkatan, yaitu: 1. Staats Fundamentalnorm/Grundnorm (norma fundamental negara); 2. Staatsgrund Gezets (aturan dasar negara/pokok negara); 3. Formell Gezets (undang-undang); 4. Verordnung \& Autonome Satzung (peraturan pelaksana dan aturan otonomi).

Pembentukan peraturan perundang-undangan harus dilakukan berdasarkan asasasas: kejelasan tujuan, kelembagaan atau pejabat pembentuk yang tepat dan kesesuaian antara jenis, hierarki serta materi muatan yang dapatdilaksanakan dan kedayagunaan serta kehasilgunaan, kejelasan rumusan dan keterbukaan. Jika hal ini diterapkan ke dalam suatu peraturan perundang-undangan, maka akan terbentuk suatu peraturan perundangundangan yang baik tanpa meninggalkan prinsip-prinsip keadilan. ${ }^{22}$ A. Hamid S. Attamimi berpendapat bahwa pembentukan peraturan perundang-undangan Indonesia yang patut, adalah sebagai berikut: Cita Hukum Indonesia; Asas Negara Berdasar Atas Hukumdan Asas Pemerintahan yang berdasar Konstitusi; Asas-asas lainnya. ${ }^{23}$

Hierarki atau tata urutan peraturan perundang-undangan di Indonesia merujuk pada Pasal 7 ayat (1) Undang-Undang Nomor 12 Tahun 2011 tentang Pembentukan Peraturan Perundang-Undangan dan perubahannya yang terdiri atas: Undang-Undang Dasar Negara Republik Indonesia Tahun 1945; Ketetapan Majelis Permusyawaratan Rakyat; Undang-Undang/Peraturan Pemerintah Pengganti Undang-Undang; Peraturan Pemerintah; Peraturan Presiden; Peraturan Daerah Provinsi; dan Peraturan Daerah Kabupaten/Kota. ${ }^{24}$ Terkait Peraturan Daerah diatur juga dalam Pasal 18 ayat 6 UndangUndang Dasar RI Tahun 1945. Perda berbeda-beda dikarenakan penampung kekhususan dan keragaman daerah serta penyalur aspirasi masyarakat di daerah.

Dari penjelasan di atas baik Peraturan Presiden dan Peraturan Daerah merupakan bagian dari hierarkhi perundang-undangan namun demikian terkait sanksi sebagai bagian di dalamnya, Prof. Andi Hamzah menegaskan hukuman pidana harus diatur pada tingkat

${ }^{21}$ Maria Farida Indrati, Ilmu Perundang-Undangan 1; Jenis, Fungsi dan Materi Muatan,(Yogyakarta: Kanisius, 2007), hlm. 41.

22 Ferry Irawan Febriansyah, Konsep Pembentukan, Peraturan Perundang-Undangan Di Indonesia, Jurnal Perspektif, Volume Xxi No. 3 Tahun 2016

${ }_{23}$ Maria Farida Indrati Soeprapto, Ilmu Perundang- Undangan: Jenis, Fungsi, Dan Materi Muatan, Kanisius, Yogyakarta, 2010, Hlm. 228.

24 https://www.hukumonline.com/klinik/detail/cl4012/ Hierarki Peraturan Perundangundangan di Indonesia 
Undang-Undang, tak boleh hanya dengan sebuah peraturan pemerintah apalagi Perda namun dimungkinkan pada daerah otonom sesuai dengan kondisi budaya, sosial, serta ekonomi setempat. Prof. Mardjono Reksodiputro berpendapat bahwa perda bisa memuat delik yang dapat dipidanakan, berupa hukuman denda. Prof. Maria Farida Indrati Soeprapto mengatakan bahwa ketentuan pidana merupakan ketentuan yang tidak mutlak ada dalam peraturan perundang-undangan, sehingga perumusan ketentuan pidana tersebut tergantung pada masing-masing peraturan perundang-undangan.

Pasal 15 angka (3) UU No. 11 Tahun 2012 tentang Pembentukan Peraturan Perundang-undangan menyatakan bahwa Peraturan Daerah Provinsi dan Peraturan Daerah Kabupaten/Kota dapat memuat ancaman pidana kurungan atau pidana denda. Kata "dapat" mengindikasikan bahwa undang-undang tidak harus selalu ada ketentuan pidana di dalamnya.

H.G. van de Bunt kriminolog Universitas Erasmus Rotterdam dan Jan Remmelink, Jaksa Agung Belanda tahun 1968-1989 berpendapat bahwa penggunaan hukum pidana, syarat untuk dapat dijadikan sebagai suatu primum remedium (tidak ada alternatif penyelesaian lain) yaitu: 1. Sangat dibutuhkan dan hukum yang lain tidak dapat digunakan (mercenary); 2. Menimbulkan korban yang sangat banyak; 3. Tersangka/terdakwa merupakan recidivist, 4. Kerugiannya tidak dapat dipulihkan (irreparable); 5.Mekanisme penegakan hukum lainnya yang lebih ringan telah tiada berdaya guna atau tidak dipandang.

Meskipun beberapa ahli memberikan pandangan bahwa hukum pidana dapat digunakan sebagai primum remedium dengan kriteria tertentu sebagaimana disebut diatas, hukum pidana seyogyanya ditempatkan sebagai instrumen terakhir (ultimum remedium) karena sejatinya hukum pidana merupakan hukum yang paling keras diantara instrumeninstrumen hukum lain yang mengontrol tingkah laku masyarakat. Penetapan sanksi pidana seyogyanya dilakukan secara terukur dan berhati-hati karena hal itu terkait dengan kebijakan peniadaan kemerdekaan dari hak asasi manusia yang dilegalisasi oleh undang-undang. Pembuatan peraturan harus mengacu pada 3 (tiga) unsur fundamental hukum yakni kepastian hukum (Rechtssicherheit), kemanfaatan (Zweckmassigkeit) dan keadilan (Gerechtigkeit). 
KRTHA BHAYANGKARA | Volume 15 Number 1, June 2021

\section{E. Asas Keadilan pada Undang-Undang No. 36 Tahun 2009 tentang Kesehatan}

Amartya Kumar Sen mencatat bahwa ketidakbebasan ekonomi (economic unfreedem) dalam bentuk kemiskinan yang ekstrem dapat menyebabkan kematian. ${ }^{25}$ Sen cenderung melihat ide keadilan sebagai upaya untuk mengurangi ketidakadilan dibanding sebagai upaya untuk melahirkan satu institusi dengan aturan yang adil secara paripurna. Ia menyebut pendekatannya sebagai pendekatan perbandingan yang berfokus pada proses realisasi (realization-focused comparison). Dalam pendekatan komparatif, kehidupan masyarakat tidak hanya ditentukan oleh institusi, tetapi juga oleh tindakan-tindakan aktual mereka dan interaksi sosial yang ada di dalamnya. ${ }^{26}$

Pendekatan kapabilitas adalah salah satu konsep sentral dalam pemikiran Sen. Iamemahami kapabilitas sebagai kemampuan untuk mencapai (the abilityto achieve) sesuatu yang dianggap bernilai. ${ }^{27} \mathrm{Hal}$ yang paling mendasar bagi hidup manusia sejatinya adalah adanya kemampuan (ability) ini. Sen menyebut konsep ini dalam banyak term. Ia kadang menyebutnya sebagai kesempatan (opportunity), daya (power) dan juga sebagai kebebasan (freedom). Hal yang ia tekankan dalam pendekatan kapabilitas bahwa ketika seseorang memiliki keinginan meraih hidup yang dianggap bernilai (preference), persoalannya kemudian adalah apakah orang tersebut memiliki kemampuan untuk mencapainya. Jika ia memiliki kemampuan itu, maka ia memiliki kapabilitas, namun jika ia tidak memilikinya, makaia kehilangan kapabilitas atau mengalami deprivasi kapabilitas. Orang atau masyarakat yang tidak bisa makan (entah karena tidak ada makanan atau karena penyakit), tidak bisa mengakses kesehatan (karena tidak punya uang) dan juga orang yang tidak bisa berpendapat secara bebas di muka umum, oleh Sen disebut sebagai orang-orang yang mengalami deprivasi kapabilitas.

Kapabilitas terkait erat dengan status sosial ekonomi, menurut Nasution dan Nur status sosial ekonomi adalah suatu tingkatan yang dimiliki oleh seseorang yang didasarkan pada kemampuan (capability) dalam memenuhi kebutuhan hidup sehari-hari dari penghasilan atau pendapatan yang diperoleh sehingga mempunyai peranan pada status sosial seseorang dalam struktur masyarakat. ${ }^{28}$ Sunarto membagi tingkatan status sosial ekonomi dalam masyarakat menjadi tiga kelas, yaitu: ${ }^{29}$

\footnotetext{
${ }^{25}$ https://majalah.tempo.co/read/iqra/85773/Amartya Sen, Keadilan, dan Kebebasan - Iqra -

${ }^{26}$ Amartya Sen, The Idea of Justice, Massachusetts, The Belknap Press of Harvard University Press Cambridge, 2009, 5-6

27 Amartya Sen, Inequality Reexamined, Oxford: Oxford University Press, 1992, 81

${ }^{28}$ Nasution, Thamrin dan Nur, Muhammad. Peranan Orang Tua dalam Meningkatkan Prestasi Belajar Anak. Jakarta: Gunung Mulia. 1986

${ }^{29}$ Sunarto, Kamanto. 2004. Pengantar Sosiologi. Jakarta: Universitas. Indonesia.
} 
a. Kelas atas (upper class), yaitu golongan keluarga atau kehidupan rumah tangga yang serba kecukupan dalam segala hal baik itu kebutuhan primer, sekunder maupun tersiernya.

b. Kelas menengah (middle class), yaitu golongan yang dalam kehidupannya tidak berlebihan akan tetapi selalu cukup dalam memenuhi kebutuhannya disesuaikan dengan kemampuan.

c. Kelas bawah (lower class), yaitu orang miskin yang mendapatkan penghasilan lebih rendah jika dibandingkan dengan kebutuhan minimal yang seharusnya mereka penuhi.

Adapun faktor-faktor yang mempengaruhi status sosial ekonomi seseorang di masyarakat, yaitu: ${ }^{30}$ pendidikan, pekerjaan atau mata pencaharian, penghasilan dan pendapatan, sosial.

Pasal 28D ayat (2) UUD NRI 1945 menentukan bahwa setiap orang berhak atas pengakuan, jaminan, perlindungan, dan kepastian hukum yang adil serta perlakuan yang sama di hadapan hukum. ${ }^{31}$ Pembangunan kesehatan diselenggarakan dengan prinsip nondiskriminatif, partisipatif, dan berkelanjutan serta berasaskan perikemanusiaan, keseimbangan, manfaat, pelindungan, penghormatan terhadap hak dan kewajiban, keadilan, gender dan nondiskriminatif dan norma-norma agama. Dalam penjelasan Pasal 2 angka (6) Undang-Undang No. 36 Tahun 2009 tentang Kesehatan dijelaskan bahwa asas keadilan berarti bahwa penyelenggaraan kesehatan harus dapat memberikan pelayanan yang adildan merata kepada semua lapisan masyarakat dengan pembiayaan yang terjangkau. Dalam hal pengadaan Vaksin, Pasal 153 UU No. 36 tahun 2009 tentang kesehatan menyatakan bahwa Pemerintah menjamin ketersediaan bahan imunisasi yang aman, bermutu, efektif, terjangkau, dan merata bagi masyarakat untuk upaya pengendalian penyakit menular melalui imunisasi.

Hal penting terdapat dalam Pasal 5 angka (3) Undang-Undang Republik IndonesiaNomor 36 Tahun 2009 tentang Kesehatan dinyatakan bahwa "Setiap orang berhak secara mandiri dan bertanggung jawab menentukan sendiri pelayanan kesehatan yang diperlukan bagi dirinya". Pasal ini tentunya dapat dilaksanakan dalam rambu-rambu yang tidak membahayakan orang lain artinya bahwa orang yang berhak menentukan sendiri pelayanan kesehatan yang diperlukan bagi dirinya adalah orang yang memang pada

30 https://www.kajianpustaka.com/2019/12/Status Sosial Ekonomi (Tingkatan, Ukuran dan Faktor yang Mempengaruhi)

31 Titon Slamet Kurnia, Mahkamah Konstitusi danHak Untuk Bebas Dari Perlakuan Diskriminasi / Constitutional Court and The Right To Be Free FromDiscrimanatory Treatment, SJurnal Konstitusi, Volume 12, Tahun Maret 2015 
kenyataannya sehat berdasarkan diagnosa dokter atau pihak yang berkompeten untuk itu, hal yang sama juga yang menjadi persyaratan orang yang menerima vaksin yaitu orang yang sehat berdasarkan diagnosa dokter.

Masyarakat kelas rendah (lower class) dalam ketidakbebasan ekonomi (economic unfreedem) cenderung tidak bisa makan, mengakses kesehatan dan berpendapat secara bebas di muka umum, kondisi-kondisi ini dapat menjadi penyebab seseorang kehilangan kapabilitasnya sehingga ia tidak kemampuan untuk mencapai (the abilityto achieve) sesuatu yang dianggap bernilai dalam hal pengaturan vaksinasi yaitu hak secara mandiri dan bertanggung jawab menentukan sendiri pelayanan kesehatan yang diperlukan bagi dirinya.

\section{F. Penerapan Sanksi Vaksinasi Covid - 19}

Kementrian Kesehatan melalui Keputusan Dirjen Pencegahan dan Pengendalian Penyakit Kementerian Kesehatan RI No. HK.02.02/4/1/2021 tentang petunjuk teknis pelaksanaan vaksinasi dalam rangka penanggulangan pandemi covid-19 terkait syarat penerima vaksin covid-19, menetapkan syarat yang harus dipenuhi oleh penerima vaksin yaitu : ${ }^{32}$

1. Tidak memiliki penyakit yang terdapat dalam format screening/penapisan. penyakit tersebut adalah:

a. pernah menderita covid-19; mengalami gejala infeksi saluran pernapasan atas (ISPA) seperti batuk/pilek/sesak napas dalam 7 hari terakhir;

b. sedang mendapatkan terapi aktif jangka panjang terhadap penyakit kelainan darah;

c. jantung (gagal jantung/penyakit jantung koroner);

d. autoimun sistemik (sle/lupus, sjogren, vaskulitis, dan autoimun lainnya);

e. penyakit ginjal kronis/sedang menjalani hemodialysis/dialysis peritoneal/transplantasi ginjal/sindroma nefrotik dengan kortikosteroid);

f. reumatik autoimun/rhematoid arthritis; penyakit saluran pencernaan kronis;

g. penyakit hipertiroid/hipotiroid karena autoimun; dan penyakit kanker, kelainan darah, imunokompromais/defisiensi imun, dan penerima produk darah/transfusi.

32 Https://Indonesia.Go.Id/Kategori/Kesehatan/2318/Sembilan Syarat Penerima Vaksin Covid-19 
2. tidak sedang hamil atau menyusui.

3. tidak ada anggota keluarga serumah yang kontak erat/suspek/konfirmasi/sedang dalam perawatan karena penyakit covid-19.

4. apabila berdasarkan pengukuran suhu tubuh calon penerima vaksin sedang demam (suhu sama atau di atas 37,5 celcius), vaksinasi ditunda sampai pasien sembuh dan terbukti bukan menderita covid-19 dan dilakukan screening ulang pada saat kunjungan berikutnya.

5. apabila berdasarkan pengukuran tekanan darah didapatkan hasil di atas atau sama dengan 140/90 maka vaksinasi tidak diberikan.

6. penderita diabetes melitus $(\mathrm{dm})$ tipe 2 terkontrol dan hba1c di bawah 58 $\mathrm{mmol} / \mathrm{mol}$ atau $7,5 \%$ dapat diberikan vaksinasi.

7. untuk penderita hiv, bila angka $\mathrm{cd} 4<200$ atau tidak diketahui maka vaksinasi tidak diberikan.

8. jika memiliki penyakit paru (asma, PPOK, TBC), vaksinasi ditunda sampai kondisi pasien terkontrol baik. untuk pasien TBC dalam pengobatan dapat diberikan vaksinasi, minimal setelah dua minggu mendapat obat anti tuberkulosis.

9. untuk penyakit lain yang tidak disebutkan dalam format penapisan ini dapat erkonsultasi kepada dokter ahli yang merawat. disarankan saat mendatangi tempat layanan vaksinasi dapat membawa surat keterangan atau catatan medis dari dokter yang menangani selama ini.

Berdasarkan syarat-syarat tersebut di atas tampak jelas bahwa bahwa sasaran penerima vaksin adalah orang yang sehat, tidak dalam keadaan terpapar virus covid-19 yang dapat menularkan kepada orang lain sehingga meskipun seseorang telah ditetapkan sebagai sasaran penerima vaksin covid-19 berdasarkan pasal 13A angka (1) Peraturan Presiden No. 14 tahun 2021 tentang perubahan atas Perpres No. 99 tahun 2020 tentang pengadaan vaksin dan pelaksanaan vaksinasi dalam rangka penanggulangan pandemi covid-19 sehingga dengan demikian demi hukum tidak dapat disebut sebagai penyebab terhalangnya pelaksanaan penanggulangan penyebaran covid-19 dan oleh karenanya tidak dapat dikenai sanksi sebagaimana Pasal 13B ataupun pasal 30 Peraturan Daerah Provinsi Daerah Khusus Ibukota Jakarta Nomor 2 Tahun 2020. Apabila sanksi tersebut dilaksanakan maka berdasarkan hierarkhi perundang-undangan telah melanggar pasal 5 angka (3) Undang-Undang Republik Indonesia Nomor 36 tahun 2009 tentang kesehatan dinyatakan bahwa "setiap orang berhak secara mandiri dan bertanggung jawab menentukan sendiri pelayanan kesehatan yang diperlukan bagi dirinya". 


\section{KESIMPULAN}

Peraturan Presiden dan Peraturan Daerah merupakan bagian dari hierarkhi perundangundangan namun demikian terkait ketentuan pidana merupakan ketentuan yang tidak mutlak ada dalam peraturan perundang-undangan, hal ini sejalan dengan Pasal 15 angka (3) UU No. 11 Tahun 2012 tentang Pembentukan Peraturan Perundang-undangan menyatakan bahwa Peraturan Daerah Provinsi dan Peraturan Daerah Kabupaten/Kota dapat memuat ancaman pidana kurungan atau pidana denda. Kata "dapat" mengindikasikan bahwa undang-undang tidak harus selalu ada ketentuan pidana di dalamnya.

Syarat penerima vaksin ditetapkan melalui Keputusan Dirjen Pencegahan dan Pengendalian Penyakit Kementerian Kesehatan RI No. HK.02.02/4/1/2021 yang pada intinya penerima vaksin adalah orang yang sehat, tidak dalam keadaan terpapar virus covid-19 yang dapat menularkan kepada orang lain, jika terjadi penolakan maka sesungguhnya tidak menjadi penyebab terhalangnya pelaksanaan penanggulangan penyebaran covid-19 dan oleh karenanya tidak dapat dikenai sanksi denda sebagaimana Pasal 13B ataupun pasal 30 Peraturan Daerah Provinsi Daerah Khusus Ibukota Jakarta Nomor 2 Tahun 2020, terlebih sanksi tersebut tidak memberikan keadilan bagi masyarakat yang tidak memiliki kapabilitas. Apabila sanksi tersebut dilaksanakan maka berdasarkan hierarkhi perundang-undangan telah melanggar pasal 5 angka (3) Undang-Undang Republik Indonesia Nomor 36 tahun 2009 tentang kesehatan dinyatakan bahwa "setiap orang berhak secara mandiri dan bertanggung jawab menentukan sendiri pelayanan kesehatan yang diperlukan bagi dirinya.

\section{SARAN}

Setiap jenis vaksin yang akan digunakan di Indonesia harus melewati uji klinis pada populasi Indonesia sebelum disuntikkan ke orang Indonesia sesuai standar World Health Organization (WHO), mendapatkan persetujuan dari Badan Pengawas Obat dan Makanan (BPOM), sertifikat halal serta dengan terlebih dahulu diadakan sosialisasi vaksinasi sehingga masyarakat menjadi sadar akan pentingnya vaksin dalam penanggulangan Pandemic Covid-19 dan serta merta menjadi pendukung upaya herd immunity ini.

Peraturan yang dibuat guna mendukung penyelesaian Pandemic Covid-19 harus mengikuti syarat-syarat pembentukan peraturan perundang-undangan serta prinsipprinsip kesehatan yaitu dengan prinsip nondiskriminatif, partisipatif, dan berkelanjutan 
serta berasaskan perikemanusiaan, keseimbangan, manfaat, pelindungan, penghormatan terhadap hak dan kewajiban, keadilan, gender dan nondiskriminatif dan norma-norma agama.

\section{DAFTAR PUSTAKA}

\section{Buku}

Amartya Sen, 2009, The Idea of Justice, Massachusetts, The Belknap Press of Harvard University Press

Amartya Sen, 1992, Inequality Reexamined, Oxford : Oxford University Press.

Amri Amir, 1997, Bunga Rampai Hukum Kesehatan, Jakarta, Widya Medika.

Erfen G.Suwangto, 2016, Pengantar Hukum Kesehatan, Jakarta, Departemen Bioetika dan Hukum Kesehatan Fakultas Kedokteran Unika Atma Jaya Jakarta.

Maria Farida Indrati Soeprapto, 2010, Ilmu Perundang- Undangan: Jenis, Fungsi, Dan Materi Muatan, Kanisius, Yogyakarta.

Nasution, Thamrin dan Nur, Muhammad. 1986, Peranan Orang Tua dalam Meningkatkan Prestasi Belajar Anak. Jakarta: Gunung Mulia

Sunarto, Kamanto. 2004. Pengantar Sosiologi. Jakarta: Universitas. Indonesia.

\section{Jurnal}

Dalinama Telaumbanua, Urgensi Pembentukan Aturan Terkait Pencegahan Covid-19 di Indonesia, Jurnal Qalamuna, Volume 12 No 1 (2020)

Ferry Irawan Febriansyah, Konsep Pembentukan, Peraturan Perundang-Undangan Di Indonesia, Jurnal Perspektif, Volume XXI No. 3 (2016)

Muh. Ali Masnun, Eny Sulistyowati Irfa Ronaboyd, Pelindungan Hukum Atas V aksin Covid19 Dan Tanggung Jawab Negara Pemenuhan Vaksin Dalam Mewujudkan Negara Kesejabteraan, Jurnal Ilmu Hukum Volume 17 No. 1 (2021)

Titon Slamet Kurnia, Mahkamah Konstitusi danHak Untuk Bebas Dari Perlakuan Diskriminasi / Constitutional Court and The Right To Be Free From Discrimanatory Treatment, Jurnal Konstitusi, Volume 12, (2015)

\section{Peraturan Perundang-undangan}

Undang-Undang Dasar Negara Republik Indonesia Tahun 1945

Undang-Undang Republik Indonesia Nomor 36 Tahun 2009 tentang Kesehatan

Undang-Undang Republik Indonesia Nomor 11 Tahun 2012 tentang Pembentukan Peraturan Perundang-undangan 
Peraturan Presiden No. 99 Tahun 2020 tentang Pengadaan Vaksin dan Pelaksanaan Vaksinasi Dalam Rangka Penanggulangan Pendemic Corona Virus Disease 2019 (Covid-19).

Peraturan Presiden No. 14 tahun 2021 Tentang Perubahan Peraturan Presiden No. 99 Tahun 2020

Peraturan Daerah Provinsi Daerah Khusus Ibukota Jakarta Nomor 2 Tahun 2020 tentang Penanggulangan Corona Virus Disease-2019.

\section{Internet}

https://www.bing.com/search?qjumlah penderita covid-19

https://kabar24.bisnis.com/read/20201026/15/1309845 Bio Farma: 7,6 Persen Orang Menolak Divaksin. Apa Alasannya?

https://health.detik.com/berita-detikhealth/d-5329447/BPOM Jelaskan Efek Samping Vaksin Sinovac yang Sudah Kantongi Izin EUA

https://mediaindonesia.com/nusantara/386919/Masih Ada Warga Menolak Vaksinasi Covid-19 di Temanggung

https://www.tribunnews.com/nasional/2021/01/13/Politisi PDIP Ribka Tjiptaning Menolak Divaksinasi, "Mending Saya Bayar Rp 5 Juta"

https://www.alodokter.com/Manfaat Vaksin Penting untuk Mencegah Penularan Penyakit

https://www.liputan6.com/news/read/4482967/Melihat Lagi Perpres Sanksi bagi Warga yang Menolak Vaksinasi

https://www.menpan.go.id/site/berita-terkini/dari-istana/Inilah Perpres 14/2021 tentang Pengadaan Vaksin dan Pelaksanaan Vaksinasi Covid-19 (menpan.go.id)

https://majalah.tempo.co/read/iqra/85773/ Amartya Sen, Keadilan, dan Kebebasan Iqra -

https://www.hukumonline.com/klinik/detail/cl4012/Hierarki Peraturan Perundangundangan di Indonesia

https://Indonesia.Go.Id/Kategori/Kesehatan/2318/Sembilan Syarat Penerima Vaksin $\underline{\text { Covid-19 }}$

https://news.detik.com/berita-jawa-timur/d-5510181/ Alasan Pengasuh Ponpes di Mojokerto Tolak Vaksin AstraZeneca.

https://www.kajianpustaka.com/2019/12/Status Sosial Ekonomi (Tingkatan, Ukuran dan Faktor yang Mempengaruhi) 